\title{
SWOT Analysis of Strengthening Education Character in Junior High School
}

\author{
Rachmat Satria ${ }^{1}$, Elvia Baby Shahbana ${ }^{2}$ \\ 1,2Universitas Negeri Malang, Indonesia
}

Corresponding Author: Rachmat Satria $\bigotimes_{\text {satriarachmat7@gmail.com* }}$

\section{ABSTRACT}

This article aimed to describe the swot analysis of education character strengthening in junior high schools which includes (1) character education curriculum management, (2) results of swot analysis of character quality improvement, and (3) the principal's strategic plan for strengthening education character based on SWOT analysis. This research was conducted at State Junior High School (SMP N) 15 Malang using a qualitative approach with a case study research design. Data was

ARTICLE INFO

Article history:

Received

April 04, 2020

Revised

August 20, 2020

Accepted

November 21, 2020

How to cite

Journal Homepage This is an open access article under the CC BY SA license collected through in-depth interviews and documentation. The results of showed that (1) education character curriculum management applied in the preparation of learning schedules, lesson plans, syllabus; and scientific journals. The Education Character Strengthening Program was formed through four components including school inputs, processes, outputs and outcomes, (2) the results of the swot analysis found that schools conduct conditional evaluations and are not tied to instruments, then reported to the Office of Education, integrating Adiwiyata values in learning and exposing the results of school work, and (3) the principal's strategic plan for strengthening education character is to use an aggressive strategy, an opportunity utilization strategy, a survival strategy, and a diversification strategy. Steps for Strengthening Education Character in learning include determining the size of the short-term and long-term programs, setting program indicators, assessing program performance, comparing performance results, connecting programs, and analyzing performance errors, and taking corrective actions.

Keywords: SWOT Analysis, Strategy, Strengthening Education Character

Satria, R., \& Shahbana, E. (2020). SWOT Analysis of Strengthening Education Character in Junior High School. Jurnal Iqra' : Kajian Ilmu Pendidikan, 5(2). 56-67. https://doi.org/10.25217/ji.v5i2.827

http://journal.iaimnumetrolampung.ac.id/index.php/ji/

https://creativecommons.org/licenses/by-sa/4.0/

\section{INTRODUCTION}

School as a system has various components consisting of inputs, processes, outputs, internal and external environment, results and impacts. Input as first components in a school system that made into output quality and competitive power through the steps in the process of being operated optimally. Meanwhile, the results were the last results obtained from the training of students both internally and externally of a system organized within the school environment. The process and learning outcomes of students will be assessed in the form of outcomes as they develop in social life. Outcomes generated by schools should bring up qualified students, possessing empathy for the social and the community (Sonhadji \& Huda, 2015). Education in schools provides hope for students to develop their potential and increase competence in terms of academics, attitudes and skills. 
However, schools must realize that there has variety problems and challenges in implementing the process and learning outcomes for students, especially in terms of Strengthening Character Education. Various issues on Strengthening Education Character are very important to be realized in the management of education. Strengthening Education Character has become a strategic issue of the Nawacita National Movement's Mental Revolution as a process of shaping the nation's character that must carried out in the current education system in Indonesia (TIM Penyusun PPK, 2017).

The Strengthening Education Character is needed. So that, students have readiness in entering the era of globalization and filtering their efforts from cultural shifts and promiscuity. Strengthening Character Education program should instilled for students to be understood and applied in all aspects of life. The positive impact of Strengthening Character Education for students in learning can help them to think flexibly, a good ethic, a good relationships and imply an emotional, social and tolerance side (Amri et al., 2020). Awareness of future challenges becomes a demand for educational institutions to realize the Golden Generation of 2045. Welcoming the Golden Generation of 2045, certainly needs to prepare a strong generation, responsive and characterized. This is marked by the digital revolution, the integration of technology and communication, transportation, corporations, the dynamics of rapid global life change, the growth of a knowledgeable, informative and networking society, creativity and innovation (TIM Penyusun PPK, 2017). Educational institutions in each region certainly continue to innovate and improve all components of learning, this strategy as a form to face competition between educational institutions in improving the quality of education. The community will measure the quality of a school by reviewing the percentage of students passing grades and school rank (Sumarni, 2011).

This phenomenon is also a strategic effort of SMPN 15 Malang, this school continues to improve, especially in terms of planting the character of students for love and care for the environment so that it can achieve the title of Adiwiyata Mandiri in 2017. The main problem faced by schools lies in differences in the background of student input when entering school, the factors underlying these problems arise from the delinquency of students due to the influence of their social environment, and in the end many cases of juvenile delinquency such as smoking, coloring hair and fighting. The negative cultural influences of the social environment around schools which are on the edge of the municipal boundaries become a weak point for educational institutions in order to build the positive character of students.

It can be understood that from the various main factors that become the problems of schools that the dimensions of the development of students include physical, emotional, social and intellectual should need to run in a balanced manner. Obviously, if these dimensions collide with one another they cause symptoms that hinder the development of personality characteristics. Siregar (2015) considers that juvenile delinquency in the area is currently very worrying due to the influence of association and social environment, besides the disharmony factor in the family environment is also an indication for students to look for a flurry outside the home. The input of students has different qualities and characters. But schools have the same goal of educating students and bequeathed qualified supplies so they can compete with world globalization. The application of strengthening education character is a joint commitment of the school community by agreeing on the character values developed by the school (Lie, 2010). 
The process of achieving the strengthening of the education character program is carried out by SMPN 15 Malang through classroom learning programs, extracurricular activities, and collaboration with outside parties such as religious leaders and the police. The initial program that the school does when recruiting students is by having a student guardian meeting to sign a memorandum of understanding (MOU) agreement with the school regarding the learning process and school discipline during the learning process. The results stated by Zurqoni et al., (2018) that education character can be implemented by preparing character improvement programs such as role models, habituation interventions and reinforcement as well as facilitating the means of character building in schools. However, heterogeneity of students and different community paradigms also become a barrier factor for schools.

Character formation for students should go hand in hand with the development of potential in themselves, so that the potential can be applied in their lives. Parents and teachers also need to accompany the pattern of adolescent life in every process of their development (Santrock, 2011). Positive forms of self potential need to be prepared by students such as religious spiritual strength, self-control, personality, intelligence, noble character and skills. Principals as the highest elements in educational institutions need to pursue some effective policies related to the progress of the current 2013 curriculum with the integration of Strengthening Education Character, literacy skills, Higher Order Thingking Skills (HOTS), and 4Cs competence (critical thinking and problem solving, creativity, communication skills, and the ability to work collaboratively) (Prayitno, 2019). A similar view was also expressed by Rianawati (2017) that moral character education needs to be integrated in every subject that is contained in national curriculum standards. Therefore, the learning programs that are carried out should be controlled and evaluated as a reference for further program improvement. Different findings obtained from the implementation of character education that overall not all teachers understand the concept of character education, there is no specific design of systematic education character strengthening programs in learning, and evaluation of character education is relatively varied (Julia \& Supriyadi, 2018). Learning programs should be controlled and evaluated as a reference for further program improvement. Therefore, the strengthening of character education is a concern for every education stakeholder so that character clashes do not occur when the process of growth and development.

Based on the above problem formulation, the purpose of this study is to describe the management of character education in schools, describe what factors are the strengths, weaknesses, opportunities and threats in improving the quality of characters, and describe the strategic plan of the principal towards strengthening character education based on SWOT analysis at SMPN 15 Malang.

\section{METHODS}

This research was conducted at SMPN 15 Malang to explore in depth information using the SWOT analysis technique on the Strengthening Education Character (PPK) program. SWOT analysis techniques are used to evaluate and compare overall strengths and weaknesses (internal factors) as well as opportunities and threats (external factors) so that the realistic goals of an institution have better advantages in the future (Kotler, 2013; Rangkuti, 2009; Sianipar \& Entang, 2003). The research method uses qualitative types to describe and analyze the object of events, social activities, attitudes, and perceptions of a person or group that has been collected and then drawn conclusions based on information and facts naturally in the field (Anggito \& Setiawan, 
2018; Conway, 2014; Killam \& Heerschap, 2013; Loeb et al., 2017). Research design with a case study approach. Data collection techniques with observation, in-depth interviews and documentation studies. Observation was carried out to see all phenomena in the form of student and teacher learning activities in strengthening education character reviewed through the instrument sheet. Researcher's interview data was obtained from in-depth interviews from Agus Wahyudi, M.Pd as the Principal, M. Shodiq, M.Pd as the deputy head of the Curriculum, Dra. Puji Sumartini as deputy head of student affairs and public relations, and Drs. Ahmad Zuhdi as deputy head of facilities and infrastructure to get the main and valid thinking related to strengthening character education. Documentation study activities are used to review the data and documents related to this research, and then conclude the data to get answers to the problems that were formulated. The results of the interview in the form of transcript data are described in narrative form which outline the overall activities of the education character improvement program in schools. And also the collection of documentation data in the field is used to support various data from interviews. Then the data analysis is done to conclude the findings obtained from the field, then the data reduction is done to group the data needed from the observations, interviews and documentation of each learning activity in school. Furthermore, conclusions are drawn from the results of research based on data obtained in the field in response to the formulation of the problems presented based on the problems faced by schools.

\section{RESULT AND DISCUSSION}

\section{The Management of Education Character Curriculum}

The current era of globalization, education character becomes a fundamental part of the nation's generation that continues to be born and developed in each individual human being. Strengthening Character Education functions to sort out and choose acculturation of foreign cultures to be more moral and civilized (Anshori, 2017). Achieving educational goals requires good management to manage various components of education that were carried out.

Curriculum managements were applied in the form of formation program and development of the preparation of learning tools includes: 1) learning schedules; 2) Lessons plan (RPP); 3) syllabus; and 4) scientific journals. The learning tool programs were composed by three staff members of the learning curriculum. The process of preparing school subject schedules were arranged one month before the implementation of the new school year, so that it could adjusted to various other learning programs. Curriculum management has managed in a complex and systematic way to realize learning objectives that were adapted to the context of School-Based Management and School-Based Curriculum (Rusman, 2009).

Meanwhile, Strengthening Character Education were formed through four components which includes: input, process, output, and school outcomes. The input of students consisted of various comparisons of character and social backgrounds, $20 \%$ of students came from Civil Servant or Indonesian Police families, while the rest came from the middle class. Thus, some of them tend to have low learning awareness. The diversity of social backgrounds also affects the lives of students, there were still many phenomena of juvenile delinquency. So that, it becomes the responsibility of schools in shaping the character of student's quality. The initial program that the school does when recruiting students was by having a student guardian meeting to sign a memorandum of understanding (MOU) agreement with the school regarding the 
learning process and school discipline during the learning process. Character building in Indonesia aims to develop the next generation of people who were virtuous in making decisions between good and bad, maintaining and spreading goodness in everyday life (Najib, Wiyani, \& Sholichin, 2016; Setiawati, 2017).

While the process of implementing character education is focused on the attainment of attitude competencies (affective domain) based on faith and piety. The school assumes that the formation of strong characters will be able to improve achievement and results competency of students both academically and nonacademically. Habitual integration of $75 \%$ character values develops and entrenches students' behavior (Sutarno, 2017). However, academic and psychomotor remain a school priority in learning activities. Internal efforts undertaken by schools in the process of character education are to improve the quality and quantity of teaching staff (counselors). The role of the counselor in providing individual and responsive services to students has a synergistic impact with a character education program (Wangid, 2010). Likewise, the role of the teacher and parent will impact on cultural change and behavior in the process of improving their character (Abdi, 2018). Meanwhile, external efforts in the process of achieving character education program strengthening were carried out by schools through classroom learning programs, extracurricular activities, to collaborating with outside schools such as religious leaders and the police.

While the Output and Outcome of students were formed through the basis of positive character values such as being friendly and familial with all school members, loving one another, courtesy, and tolerance. Ekowarni explained that, the basic values of behavior that become a reference in the social order were based on the pillars of peace, mutual respect, cooperation, freedom, peace, honesty, humility, compassion, responsibility, simplicity, tolerance and unity (Zubaedi, 2011). Integration of character values in learning means gathering, immersing and practicing every value of knowledge, awareness and willingness that was believed to be true to shape the character and identity of learners (Ghufron, 2010). However, the gap between expectations and reality also still a problem of schools in shaping the positive character of students. The fact that there were some cases that require special guidance where some of them still have a low level of education awareness, juvenile delinquency, and the use of illegal drugs. The action was motivated by the influence of association and social environment in searching fun outside the home and the disharmony of the relationship between parent and child at home (Siregar, 2015).

\section{SWOT Analysis Results of Improving Character Quality}

Based on the phenomena described earlier, the school need to make a strategic planning effort to improve the character quality of students at school. Improving the quality of characters includes aspects of input, process, output and school outcomes. It is endeavored to ensure continuity with learning programs for students. Schools conduct conditional evaluations and are not bound by existing instruments, each of these programs is reported to the relevant Education Office as an evaluation of the government. The school's strategy in strengthening character is by continuing to foster collaboration from the Adiwiyata program where, since 2017 Junior High School 15 Malang has become an Adiwiyata Mandiri School, and utilizes all forms of social media to expose the results of school work.

The school strategy formulation also needs to be done through the analysis of Strengths, Weaknesses, Opportunities, and Threats (SWOT). The results of the analysis form the basis of review and evaluation for schools to find more optimal strategy 
formulas in shaping the positive character of students. The SWOT analysis Junior High School 15 Malang as follows:

Table 1.1 SWOT Analysis of Junior High School 15 Malang

\section{Internal and External Analysis of School}

\begin{tabular}{|c|c|}
\hline $\mathbf{S}$ & $\begin{array}{l}\text { - Adiwiyata Mandiri school status } \\
\text { - } \text { Active extra-curricular activities. } \\
\text { - Strogration of Adiwiyata values in each subject. } \\
\text { - Improving academic students with additional hours of study and extra- } \\
\text { curricular Olympics. } \\
\text { Utilization of school committees and parents to provide lunch for students who } \\
\text { would be intensive in National Examination. } \\
\text { Principals, teachers, and educators provide examples of good attitudes for } \\
\text { students. }\end{array}$ \\
\hline W & $\begin{array}{l}\text { Low academic input of students. } \\
\text { - Parents' backgrounds are relatively evenly distributed (not only the upper } \\
\text { middle class). } \\
\text { - Awareness of student education is still low. }\end{array}$ \\
\hline O & $\begin{array}{l}\text { Integration of Malang Culture into extracurricular activities and learning in } \\
\text { class. } \\
\text { - Open business opportunities for students' work and handicrafts to be promoted } \\
\text { at each Malang City event. }\end{array}$ \\
\hline $\mathbf{T}$ & - The influence of juvenile delinquency from the environment around the school. \\
\hline
\end{tabular}

Based on the SWOT analysis table above, schools can determine the form of strengths and strengths of schools (Strengths), weaknesses in the form of unsupportive components of what schools want to achieve (Weaknesses), opportunities that might be achieved and developed from the potential contained in the school (Opportunities), and threats from possible influences occurred in the administration of schools (Threats) (Rangkuti, 2009).

The data generated from the SWOT Analysis helps schools to formulate meaningful changes in the programs that are run (Orr, 2012). The strategic plan in managing an educational institution becomes an absolute thing to face competition between educational institutions both in terms of quality and quantity. Implementation of Strengthening Character Education is not a separate and separate subject, but rather the integration of each subject, self-expansion, school culture and local content (Judiani, 2010). The following is a SWOT analysis diagram:

\begin{tabular}{l|l} 
I & \multicolumn{1}{|c}{ II } \\
$\begin{array}{l}\text { An increase in the concentration of } \\
\text { religious studies. }\end{array}$ & $\begin{array}{l}\text { Develop character building programs for } \\
\text { students. }\end{array}$ \\
$\begin{array}{l}\text { Forming cooperation with internal and } \\
\text { external parties in strengthening character } \\
\text { education. }\end{array}$ & $\begin{array}{l}\text { Establish community participation in } \\
\text { supporting learning programs. } \\
\text { Facilitating the interests and talents of } \\
\text { students through additional curricular } \\
\text { education programs effectively and } \\
\text { eftivities. }\end{array}$ \\
$\begin{array}{l}\text { Increasing the content of Adiwiyata in the } \\
\text { learning curriculum. }\end{array}$ \\
School commitment in making characters
\end{tabular}




\begin{tabular}{l|l} 
for students. & \\
\hline $\begin{array}{l}\text { Hold productive and innovative activities } \\
\text { at school. }\end{array}$ & $\begin{array}{l}\text { Make counseling activities against } \\
\text { juvenile delinquency. }\end{array}$ \\
School principals, teachers and educators & $\begin{array}{l}\text { Improving the achievement of non- } \\
\text { apply the motto Ki Hajar Dewantara (Ing } \\
\text { academic grades in schools optimally. }\end{array}$ \\
Ngarso Sung Tulodho, Ing Madyo Mangun & \\
Karso, Tut Wuri Handayani). & \\
School rules policies related to handling \\
juvenile delinquency.
\end{tabular}

\section{Figure 1.1 School Strategy For Each Quadrants}

Refer to Figure 1 above, show some of the school's strategic plans in improving character education to students with emphasis on universal values. The SWOT analysis provides a reflective picture of what schools will face in the future. Educational institutions try to instill core values through the learning process. 21st century learning studies are directed to encourage independence in exploring various sources, summarize problems, think logically, and collaboratively (Komara, 2018). The expected outcome is to provide a revision of coaching that is relevant and appropriate to the needs of students in facing global challenges (Wijaya, 2015).

\section{The Principal's Strategic Plan for Strengthening Education Character}

The principal plays a role in controlling the learning and implementation of school activities in developing the character quality of students. Controls were taken to review and ensure the implementation of the whole program to be achieved, compare performance results, and take corrective actions. The steps taken by the principal related to Strengthening Character Education in learning, include: 1) determining the size of the short-term and long-term programs to be achieved; 2) set the standard indicators of schools' achievement programs; 3) assessing the performance of the running program; 4) comparing performance results with established standards, connecting programs that have been realized, and analyzing performance errors; and 5) taking corrective actions against performance errors. Control procedures produce information from the implementation of education program strategies and policies (Fattah, 2013). Decision making on program improvement was carried out through setting priorities to determine the priority of the program to be implemented. Determination of the priority scale starts with assessing the needs of the program, it could be seen in the implementation of program objectives in schools that include aspects of academics, skills, and attitudes of students in learning. The demand and needs of consumers of educational services for learning programs and improvement of Human Resources are challenges for schools that need to be accessed precisely, carefully, and accurately (Sonhadji \& Huda, 2015; Widodo, 2019).

The finding of this research showed that the principal's strategy for Strengthening Character Education includes: 1) An aggressive strategy (S-O): increasing concentration on religious studies for students by involving the participation of various elements of education, forming cooperation with stakeholders and consumers of education in improving the quality of character, gathering the interests and talents of students through extra-curricular activities, the integration of Adiwiyata's content into the learning curriculum, and the school's commitment to shape character integrity to students; 2) Opportunity utilization strategy (W-O): develop innovative character building programs for students, establish community 
participation in supporting learning programs, form an Evaluation Team for Strengthening Character Education programs effectively and efficiently; 3) Defensive strategy (W-T): make counseling activities towards juvenile delinquency, increase the achievement of non-academic values of students optimally in learning; 4) Diversification Strategy (S-T): holding productive and innovative activities in schools, school principals, teachers and educators applying the slogan Ki Hajar Dewantara (Ing Ngarso Sung Tulodho, IngMadyo Mangun Karso, Tut Wuri Handayani) in character education, making policies school related rules handling juvenile delinquency around the school environment. Different findings suggest that apart from analyzing the environment and externals with a SWOT analysis, it is necessary to load the core values of the school's short and middle-term strategic plans and also the school literacy movement (GLS) for continuous improvement (Rohmayanti, 2019). Some of the other strategic findings of the Strengthening Character Education program were developed with cultural and community-based classroom programs. In addition, it is also supported by the leadership of the principal, commitment to community participation, utilization of environmental potential and the development of facilities and infrastructure with local wisdom (Sriah, 2018). The implementation of this program can be realized by integrating extracurricular activities into the school curriculum (Aini, Hanief, \& Mustafida, 2020).

However, the example of parents, teachers and community leaders is a strategic key to building the character of students integrated with religious and cultural teaching (Umar, Hendra, \& Yussof, 2019). Great attention from schools, families, and communities plays an important role in increasing the goal of Strengthening Character Education that is holistic and integrated (Nurfadhilah, 2019). Other findings were found that by using SWOT analysis techniques in the integration of e-learning related to institutional aspects, teaching aspects and investment aspects can provide strength and opportunities for academic staff in improving university quality (Zhu \& Justice Mugenyi, 2015). Meanwhile, related to the strategic plan based on the Delphi Futures Research Ethnographic Approach towards education towards lifelong learning in Thailand can help institutions in strengthening policy making and changing learning support tools (Charungkaittikul, Ratana-Ubol, \& Henschke, 2019). However, there are still obstacles to the implementation of strategic plans still within the average level in Anambra State secondary schools where the strategic plan policy percentage ranges from 3.39 to 4.65 or below the average level. Principals and staff need to increase commitment to have more planned goals that will be developed in future school strategic plans (Chukwumah, 2015; Chukwumah \& Ezeugbor, 2015). In other words, the SWOT analysis technique is a tool to measure the impact of the gap between methodological and implementation challenges (Leiber, Stensaker, \& Harvey, 2018).

The implications of this research can be applied by schools in the preparation of strategic plans to improve student character education by using SWOT analysis techniques. There is a separate effort from the government to conduct training on the strengthening of character education programs to broaden the knowledge of teachers in schools (Nur Aisyah, Samawi, \& Fitri Untariana, 2018). From the results of the analysis conducted can help schools in determining the size of the short-term and longterm programs and set program indicators in the next program policies. Each school certainly has its own problems in organizing educational programs for students, so it is necessary to improve the quality of education through strategic programs in order to be able to answer the problems that arise in the future. 


\section{CONCLUSIONS}

Strengthening Character Education was aims to make students more ready in entering the era of globalization and filtering their efforts from cultural shifts and promiscuity. Based on the research, it could be concluded that; First, character education curriculum management was applied in the preparation of learning schedules, lessons plan, syllabus; and scientific journals. Strengthening Character Education programs were formed through four components: covering school inputs, processes, outputs and outcomes. Second, the results of the SWOT analysis found that schools conducted conditional evaluations and were not bound existing instruments, and reported to the Department of Education as material for evaluating the government, integrating Adiwiyata values in learning and exposing the results of school work. Third, the principal's strategic plan for strengthening character education was to use aggressive strategies, opportunity utilization strategies, survival strategies, and diversification strategies. Principals' steps towards Strengthening Character Education in learning, including determining the size of the short-term and long-term programs, setting program indicators, assessing program performance, comparing performance results, synchronize programs, and analyze performance errors, and take corrective actions.

\section{ACKNOWLEDGEMENTS}

The authors were sincere appreciation to Principal of SMPN 15 Malang for giving permission to do my research. Then, thanks to the Supervising Lecturer for the guidance and direction to the author to immediately complete this research. And finally, thank for the team who contributed their thoughts and time in completing this research.

\section{AUTHOR CONTRIBUTION STATEMENTS}

Rachmat Satria (RS) is the main author in this paper. Elvia Baby Shahbana (EBS) is the second author to provide support to become a comparative researcher. Authors are a Master of Management Education in State University of Malang. The authors had participated in the research and approved the final version of the manuscript.

\section{REFERENCES}

Abdi, M. I. (2018). The Implementation of Character Education in Kalimantan, Indonesia: Multi Site Studies. Dinamika Ilmu, 18(2), 305-321. Google Scholar

Aini, M. S. N., Hanief, M., \& Mustafida, F. (2020). Implementasi Nilai-Nilai Karakter Untuk Meningkatkan Kecerdasan Spritual Siswa di SD Islam Bani Hasyim Kabupaten Malang. Jurnal Pendidikan Madrasah Ibtidaiyah, 2(2), 72-81. Google Scholar

Amri, S., Ismawati, T., \& Armila, A. (2020). Studi Analisis Nilai Nilai Pendidikan Karakter Perspektif Syech Muhammad Khudhari Bek dalam Kitab Khulashah Nurul Yakin. Attractive: Innovative Education Journal, 2(2), 77-88. Google Scholar

Anggito, A., \& Setiawan, J. (2018). Metodologi penelitian kualitatif. Jawa Barat: CV. Jejak. Google Scholar

Anshori, I. (2017). Penguatan Pendidikan Karakter di Madrasah. Halaqa: Islamic Education Journal, 1(2), 63-74. https:// doi.org/10.21070/halaqa.v1i2.1243

Charungkaittikul, S., Ratana-Ubol, A., \& Henschke, J. A. (2019). Strategies to Reorienting Higher Education Institutions toward Lifelong Learning Higher Education Institutions in Thailand. International Journal of Adult Vocational 
Education and Technology, 10(4), 16-29. https:// doi.org/10.4018/IJAVET.2019100102

Chukwumah, F. O. (2015). Developing Quality Strategic Plan in Secondary Schools for Successful School. Journal of Education and Practice, 6(21), 136-144. Google Scholar Chukwumah, F. O., \& Ezeugbor, C. O. (2015). Problems of Implementation of Strategic Plans For Secondary Schools Improvement in Anambra State. Educational Research and Reviews, 10(10), 1384-1389. https:// doi.org/10.5897/err2015.2177

Conway, C. M. (2014). The Oxford Handbook of Qualitative Research in American Music Education. New York: Oxford University Press. Google Scholar

Fattah, N. (2013). Analisis Kebijakan Pendidikan. Bandung: PT. Remaja Rosdakarya. Google Scholar

Ghufron, A. (2010). Integrasi Nilai-Nilai Karakter Bangsa Pada Kegiatan Pembelajaran. Cakrawala Pendidikan, XXIX(Edisi Khusus Dies Natalis UNY), 13-24. Google Scholar

Judiani, S. (2010). Implementasi Pendidikan Karakter di Sekolah Dasar Melalui Penguatan Pelaksanaan Kurikulum. Jurnal Pendidikan Dan Kebudayaan, 16(Edisi Khusus III), 280-289. https:/ / doi.org/10.24832/jpnk.v16i9.519

Julia, \& Supriyadi, T. (2018). The Implementation of Character Education at Senior High School. SHS Web of Conferences, 42(00085), 1-6. https:// doi.org/10.1051/shsconf/20184200085

Killam, L. A., \& Heerschap, C. (2013). Nurse Education Today Challenges to Student Learning in The Clinical Setting: A Qualitative Descriptive Study. Nurse Education Today, 33(6), 684-691. https://doi.org/10.1016/j.nedt.2012.10.008

Komara, E. (2018). Penguatan Pendidikan Karakter dan Pembelajaran Abad 21. SIPATAHOENAN: South-East Asian Journal for Youth, Sports \& Health Education, 4(1). https:/ / doi.org/10.2121/sip.v4i1.991.g889

Kotler, P. (2013). Manajemen Pemasaran (7P) (terjemahan). Jakarta: PT. Erlangga. Google Scholar

Leiber, T., Stensaker, B., \& Harvey, L. C. (2018). Bridging Theory and Practice of Impact Evaluation of Quality Management in Higher Education Institutions: A SWOT Analysis. European Journal of Higher Education, 8(3), 351-365. https:// doi.org/10.1080/21568235.2018.1474782

Lie, A. (2010). Guru Belum Terapkan Pendidikan Karakter. https://www.buntetpesantren.org/2010/01/guru-belum-terapkan-pendidikankarakter.html

Loeb, S., Dynarski, S., Mcfarland, D., Morris, P., Reardon, S., \& Reber, S. (2017). Descriptive Analysis in Education: A Guide For Researchers. Washington, DC: U.S. Department of Education, Institute of Education Sciences, National Center for Education Evaluation and Regional Assistance. Google Scholar

Najib, M., Wiyani, N. A., \& Sholichin. (2016). Manajemen Strategik Pendidikan Karakter Bagi Anak Usia Dini. Yogyakarta: Gava Media. Google Scholar

Nur Aisyah, E., Samawi, A., \& Fitri Untariana, A. (2018). Efforts to Improve the Ability of The Teachers in Development Program for Strengthening Character Education (PPK) in Early Childhood Education (ECE) through Workshop Activities. 1st International Conference on Early Childhood and Primary Education (ECPE 2018), 244(Ecpe), 38-41. https:// doi.org/10.2991/ecpe-18.2018.9

Nurfadhilah. (2019). Analisis Pendidikan Karakter Dalam Mempersiapkan Pubertas Menuju Generasi Emas Indonesia 2045. Jurnal Pendidikan Dasar, 10(1), 85-100. https:// doi.org/10.21009/10.21009/JPD.081 
Orr, B. (2012). Conducting a S.W.O.T. Analysis for Program Improvement. 3(6), 381-384. Google Schoolar

Prayitno, W. (2019). Bahan Ajar Pengenalan Pembelajaran dan Penilaian Kurikulum 2013 (Terintegrasi PPK, Literasi, HOTS, 4cs) (Bahan Pemb; C. Triatna \& E. Z. Zahara, Eds.). Direktorat Jenderal Guru dan Tenaga Kependidikan Kementerian Pendidikan dan Kebudayaan Republik Indonesia. Google Scholar

Rangkuti, F. (2009). Analisis SWOT Teknik Membedah Kasus Bisnis. Jakarta: PT. Gramedia Pustaka Utama. Google Scholar

Rianawati. (2017). The Implementation of Education Character on Moral in MTsN (Islamic Junior High State School) 1 Pontianak in the Academic Year 2015/2016. Journal of Education and Practice, 8(9), 186-195. Google Scholar

Rohmayanti, L. (2019). Strategic Management of Increasing Competency of Students Though Strengthening Character Education (PPK) and School Literation Movement (GLS) at Muhammadiyah Junior High School Margasari. International Conference of Moslem Society, 3(2010), 129-148. https:// doi.org/10.24090/icms.2019.2434

Rusman. (2009). Manajemen Kurikulum. Jakarta: PT. Raja Grafindo Persada. Google Scholar

Santrock. (2011). Perkembangan Masa Hidup (Terjemahan). Jakarta: Erlangga. Google Scholar

Setiawati, N. A. (2017). Pendidikan Karakter Sebagai Pilar Pembentukan Karakter Bangsa. Prosiding Seminar Nasional Tahunan Fakultas Ilmu Sosial Universitas Negeri Medan, 1(1), 348-352. Google Scholar

Sianipar, J. P. ., \& Entang, H. M. (2003). Teknik-Teknik Analisis Manajemen: Bahan Ajar DIKLATPIM Tingkat III. Jakarta: Lembaga Administrasi Negara. Google Scholar

Siregar, N. S. S. (2015). Latar Belakang Tindakan Kenakalan Anak pada Usia 13 sampai 17 Tahun. Jurnal Ilmu Pemerintahan Dan Sosial Politik, 3(1), 87-102. Google Scholar

Sonhadji, A., \& Huda, M. A. (2015). Asesmen Kebutuhan, Pengambilan Keputusan, dan Perencanaan. Malang: UM Press.

Sriah. (2018). Analisis Implementasi Kebijakan Program Penguatan Pendidikan Karakter Di Sekolah Dasar Kota Malang (Universitas Muhammadiyah Malang). Google Scholar

Sumarni, N. (2011). Strategi Peningkatan Mutu Sekolah Berdasarkan Analisa SWOT Pada SMP Kristen Satya Wacana Salatiga. Salatiga: Program Pasca Sarjana Magister Manajemen Pendidikan.

Sutarno. (2017). Pengelolaan Integrasi karakter dalam Pembelajaran Akhlak di SMP Muhammadiyah 2 Surakarta. Universitas Muhammadiyah Surakarta. Google Scholar

TIM Penyusun PPK. (2017). Konsep dan Pedoman Penguatan Pendidikan Karakter: Tingkat Sekolah Dasar dan Sekolah Menegah Pertama (L. Muliastuti, Ed.). Google Scholar

Umar, Hendra, \& Yussof, M. H. B. (2019). Building Children's Character: Ethnographic Study of Maja Labo Dahu Culture at Bima Community. Jurnal Iqra': Kajian Ilmu Pendidikan, 4(2), 182-201. https:/ / doi.org/10.25217/ji.v4i2.582

Wangid, M. N. (2010). Peran Konselor Sekolah Dalam Pendidikan Karakter. Cakrawala Pendidikan, XXIX(Edisi Khusus Dies Natalis UNY), 173-186. Google Schoolar

Widodo, H. (2019). Revitalisasi Sekolah Berbasis Budaya Mutu. Jurnal Administarsi Pendidikan, 26(1), 57-71. https:// doi.org/10.29313/tjpi.v7i2.4139

Wijaya, H. (2015). Analisis SWOT Tentang Pembinaan Kesiswaan dan Pengembangan Program Pembinaan Siswa. Google Schoolar

Zhu, C., \& Justice Mugenyi, K. (2015). A SWOT Analysis of The Integration of E- 
Learning at A University in Uganda and A University in Tanzania. Technology, Pedagogy and Education, 24(5), 1-19. https:// doi.org/10.1080/1475939X.2015.1093537

Zubaedi. (2011). Desain Pendidikan Karakter: Konsepsi dan Aplikasinya Dalam Lembaga Pendidikan. Jakarta: Kencana. Google Scholar

Zurqoni, Retnawati, H., Arlinwibowo, J., \& Apino, E. (2018). Strategy and Implementation of Character Education in Senior High Schools and Vocational High Schools. Journal of Social Studies Education Research, 9(3), 370-397. Google Scholar

\section{Copyright Holder :}

(C) Satria, R., \& Shahbana, E. (2020)

First Publication Right :

(C) Jurnal Iqra' : Kajian Ilmu Pendidikan

This article is under:

(ㅇ) (1) (2) 